\title{
First detection of the bloom forming Unruhdinium penardii (Dinophyceae) in a Mediterranean reservoir: insights on its ecology, morphology and genetics
}

\author{
Cecilia Teodora Satta, ${ }^{1 *}$ Albert Reñé, ${ }^{2}$ Bachisio Mario Padedda, ${ }^{1}$ Silvia Pulina, ${ }^{1}$ Giuseppina Grazia Lai, ${ }^{1}$ Oriana Soru, ${ }^{3}$ \\ Paola Buscarinu, ${ }^{3}$ Tomasa Virdis, ${ }^{3}$ Salvatore Marceddu, ${ }^{4}$ Antonella Lugliè ${ }^{1}$
}

${ }^{1}$ Department of Architecture, Design and Urban Planning, University of Sassari, Via Piandanna 4, Sassari, Italy; ${ }^{2}$ Institut de Ciències del Mar-CSIC, Dpt. Biologia Marina i Oceanografia, Passeig Marítim de la Barceloneta 37-49, 08003, Barcelona, Spain; ${ }^{3}$ Ente Acque della Sardegna (ENAS), Via Mameli 88, Cagliari, Italy; ${ }^{4}$ Institut of Sciences of Food Production, National Research Council (CNR), Li Punti, SS, Italy

\begin{abstract}
The freshwater genus Unruhdinium includes dinoflagellates hosting a tertiary diatom endosymbiont. Some of the species belonging to this genus form high-biomass blooms. In this study, data on the ecology, morphology and molecular identity of Unruhdinium penardii were reported for the first time from a Mediterranean reservoir (Cedrino Lake, Sardinia, Italy). The ecology of the species and its bloom events were examined along a multiannual series of data (2010-2017). Cell morphology was investigated using field samples and six cultures established by cell isolation. A molecular identification of the six strains was performed. Wild and cultured cells shared the same morphology, showing a prominent apical pore complex and two/three more or less prominent hypothecal spines as distinctive characters in light microscopy. Molecularly, the six cultured strains corresponded to the same taxonomic entity with sequences only differing in a few polymorphic positions for the studied markers SSU rDNA, LSU rDNA, ITS and endosymbiont SSU rDNA. All markers showed $99.5 \%-100 \%$ similarity with the available $U$. penardii sequences. Seasonality of $U$. penardii revealed its preference for the colder semester (from December to June) with bloom events restricted to late winter/early spring months. Three blooms resulting in reddish water discolorations were observed along the study period (2011, 2012 and 2017). GLMs revealed a significant role of water depth, temperature, and reactive phosphorous in determining the highest cell densities $\left(>5 \times 10^{4}\right.$ cells $\left.\mathrm{L}^{-1}\right)$. The results obtained contribute to the increase of field ecology knowledge on this species, demonstrating it is well established in the Mediterranean area, and being able to produce recurrent high biomass blooms in the studied reservoir.
\end{abstract}

\section{INTRODUCTION}

The genus Unruhdinium was erected in 2017 by Gottschling et al. (2017) encompassing species previously included in the genus Peridiniopsis (Gottschling et al., 2017; Moestrup and Calado, 2018). It belongs to the monophyletic family of Kryptoperidiniaceae (Kretschmann et al., 2018 and references therein), which includes dinoflagellates hosting a tertiary diatom endosymbiont (i.e., dinotoms; Imanian et al., 2011). The Unruhdinium genus includes 7 freshwater species usually hosting Cyclotellalike diatoms as endosymbionts. The morphological diagnostic traits of Unruhdinium species are the reduced number of epithecal plates and the presence of five cingular plates (Gottschling et al., 2017; Moestrup and Calado, 2018). All the species included in the genus were previously included in the genus Peridiniopsis (Gottschling et al., 2017; Moestrup and Calado, 2018).

All Unruhdinium species except $U$. jiulongensis $(\mathrm{Gu})$ Gottschling and $U$. armebeense (Ten-Hage, K.P. Da, Couté) Moestrup et Calado, were reported as high biomass bloom formers in various lakes and reservoirs worldwide (Rodriguez et al., 1999; Liu et al., 2008; Takano et al., 2008; Zhang et al., 2011; Zhang et al., 2014), including some Italian alpine lakes (Hansen and Flaim, 2007). In Mediterranean reservoirs, dinoflagellate blooms have been detected since the seventies and they have been mainly caused by Ceratium hirundinella (Muiller) Dujardin (Lugliè et al., 2001; Pérez-Martìnez and Sànchez-Castillo, 2001; Fadel et al., 2015; Mariani et al., 2015) and Gymnodinium uberrimum (G.J. Allman) Kofoid and Swezy (Fadda et al., 2016). In the last decade, intense blooms accompanied by reddish-brown water discolorations were recorded in the Cedrino Lake (Sardinia, Mediterranean region; Padedda et al., 2017). On those occasions, the responsible dinoflagellate was first recognized as a Peridinium species. A subsequent more accurate identification attributed the observed specimens to the genus Peridiniopsis. In this study, the morphological and molecular identification of the species involved in the Cedrino Lake blooms were investigated on field samples and on cultured strains and thus determined as Unruhdininium penardii (Lemmermann) Gottschling. The morphology and abundance of resting cysts from the sediments were also determined. Furthermore, the field ecology of the species was explored.

\section{METHODS}

\section{Study area, sampling strategy and analyses}

Cedrino Lake is located in the central-eastern Sardinia (western Mediterranean, Italy; Fig. 1). Its surface area is $1.5 \mathrm{~km}^{2}$ and the mean depth is $26.5 \mathrm{~m}$. The lake is eutrophic and its waters are exploited for potable and agricultural uses (Padedda et al., 2015, 2017). Cyanobacteria, including potentially toxic species, dominate the phytoplankton composition especially in summer (Messineo et al., 2009; 
Padedda et al., 2017). Cedrino Lake belongs to the Italian Network of Long Term Ecological Research (LTER-Italy; deims.org/9010f9db-3d6b-4253-9604-4e10f6714000). The Regional Sardinian Agency 'Ente Acque della Sardegna' (ENAS) is the manager of the Cedrino Lake since 2006.

Samplings were conducted from July 2010 to May 2018 at one station close to the deepest part of the lake (Fig. 1) following different patterns (Supplementary Tab. 1). In fact, the data collection activities were carried out under various projects with different objectives. Consequently, samplings were conducted monthly in 2010 and 2011 and bi-monthly from 2012 to 2018 (Supplementary Tab. 1). During the sampling period several interruptions occurred, mainly due to adverse weather conditions or sampling difficulties. Water samples were collected from selected water depth layers using a Niskin bottle. Samples for phytoplankton and chlorophyll $a$ (Chla) analyses were collected from $0,1,2.5,5,7.5$ and $10 \mathrm{~m}$ water depth layers.
Phytoplankton samples were immediately fixed in Lugol's iodine solution ( $1 \%$ final concentration) for the cell density estimate, determined following Utermohl (1958) under an inverted microscope Axiovert 25 (Carl Zeiss, Oberkochen, Germany) at 200x magnification. Further non-fixed samples were taken for the observation of live cells, for cell culturing and for formalin-fixation. Cell counts were made for each of the six depths from 2010 to 2013, whereas only one sample corresponding to the depth with the highest Chla was counted from 2014 to 2018. Chla was determined as described by Goltermann et al. (1978).

Water temperature (Temp), conductivity (Con), dissolved oxygen (DO) and $\mathrm{pH}$ were measured in situ with multi-parameter probes (YSI 6600 V2 and Hydrolab DS5). Transparency was measured with a Secchi disk (SD). Euphotic zone depth was calculated using SD measures (Zeu: 2.5 times the SD depth; Poikane, 2009). Water samples for nutrient analyses were collected from

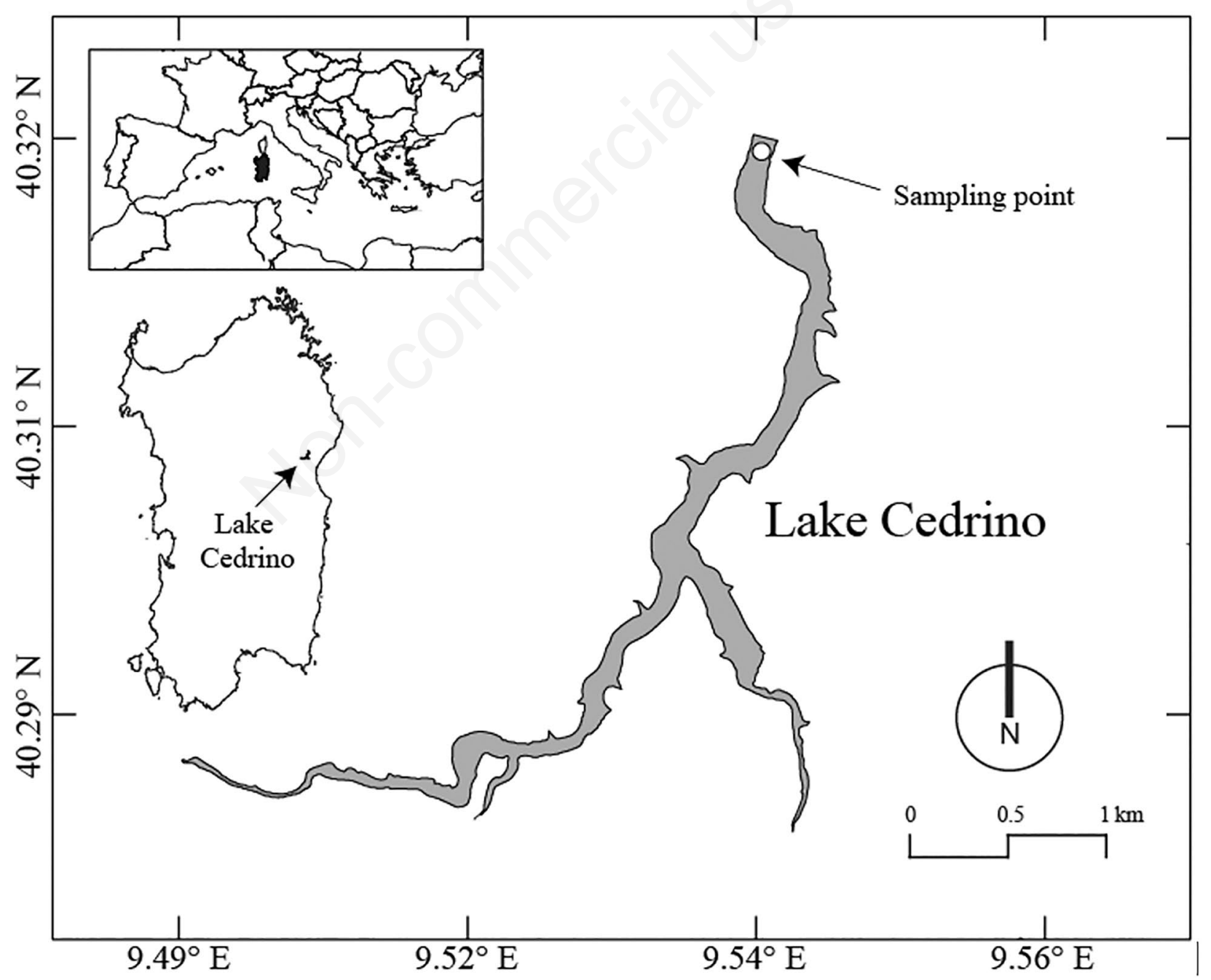

Fig. 1. Geographical location of the Cedrino Lake (Sardinia, Italy) and sampling station placement. 
each of the selected water depth layers $(0,1,2.5,5,7.5$, and $10 \mathrm{~m}$ ) plus further depth layers along the entire water column $(15,20$, and $30 \mathrm{~m})$. Concentrations of nutrients such as reactive $\left(\mathrm{P}-\mathrm{PO}_{4}\right)$ and total (TP) phosphorus, ammonium $\left(\mathrm{N}-\mathrm{NH}_{4}\right)$, nitrate $\left(\mathrm{N}-\mathrm{NO}_{3}\right),\left(\mathrm{N}-\mathrm{NO}_{2}\right)$ and total nitrogen (TN), were determined according to the methods of Strickland and Parsons (1972). Total dissolved inorganic nitrogen (DIN) was calculated as the sum of $\mathrm{N}$ $\mathrm{NH}_{4}, \mathrm{~N}-\mathrm{NO}_{3}$, and $\mathrm{N}-\mathrm{NO}_{2}$.

Surface sediment samples were taken with a grab at

Tab. 1. Unruhdinium penardii cell densities in the samples corresponding to the highest chlorophyll $a$ values at each data sampling in the photic zone and $U$. penardii cell densities and chlorophyll $a$ values calculated as weighted average in the photic zone. Data corresponding to $U$. penardii cell densities higher than $5 \times 10^{4}$ cells $\mathrm{L}^{-1}$ are reported in bold.

\begin{tabular}{|c|c|c|c|c|c|c|c|}
\hline & & $\begin{array}{c}\text { U. pen } \\
\left.\text { (cells } \times 10^{3} \mathrm{~L}^{-1}\right)\end{array}$ & $\begin{array}{l}\text { Depth } \\
(\mathrm{m})\end{array}$ & $\begin{array}{c}\text { Chla } \\
\left(\mathrm{mg} \mathrm{m}^{-3}\right)\end{array}$ & $\begin{array}{c}\text { U. pen WA } \\
\left(\text { cells } x 10^{3} \mathrm{~L}^{-1}\right)\end{array}$ & $\begin{array}{l}\text { Chla WA } \\
\left(\mathrm{mg} \mathrm{m}^{-3}\right)\end{array}$ & $\begin{array}{l}\text { Disc } \\
(\mathrm{m})\end{array}$ \\
\hline \multirow[t]{5}{*}{2010} & Jul & 0 & 2.5 & 17.5 & 0 & 19.6 & 1.0 \\
\hline & Aug & 0 & 1 & 18.5 & 0 & 17.3 & 1.5 \\
\hline & Sep & 0 & 0 & 56.9 & 0 & 51.1 & 1.5 \\
\hline & Oct & 0 & 0 & 14.6 & 0 & 11.5 & 1.2 \\
\hline & Dec & 5.8 & 1 & 0.6 & 3.5 & 0.3 & 2.5 \\
\hline \multirow[t]{10}{*}{2011} & Jan & 0 & 1 & 0.6 & 0 & 0.3 & 3.0 \\
\hline & Feb & 0 & 7.5 & 1.1 & 2.1 & 0.7 & 1.1 \\
\hline & Mar & 758.2 & 2.5 & 21.9 & 710.9 & 18.3 & 2.0 \\
\hline & Apr & 5.9 & 5 & 24.1 & 16.6 & 18.8 & 1.7 \\
\hline & May & 0 & 0 & 0.9 & 1.6 & 0.6 & 3.0 \\
\hline & Jun & 0 & 1 & 4.9 & 0 & 4.2 & 2.3 \\
\hline & Jul & 0 & 1 & 8.2 & 0 & 7.0 & 1.7 \\
\hline & Aug & 0 & 1 & 29.2 & 0 & 27.4 & 1.5 \\
\hline & Sep & 0 & 0 & 58.8 & 2.6 & 50.9 & 1.0 \\
\hline & Dec & 4.0 & 2.5 & 0.1 & 2.3 & 0.1 & 1.6 \\
\hline \multirow[t]{6}{*}{2012} & Feb & 25,632 & $\mathbf{0}$ & 359.7 & 9380.9 & 151.92 & 0.7 \\
\hline & Apr & 1.9 & 1 & 1.0 & 0.8 & 0.4 & 7 \\
\hline & Jun & 10.1 & 0 & 101.8 & 10.5 & 99.0 & 0.6 \\
\hline & Aug & 0 & 2.5 & 78.2 & 0 & 70.2 & 0.5 \\
\hline & Oct & 0 & 1 & 29.1 & 0 & 24.7 & 1.8 \\
\hline & Dec & 0 & 0 & 14.4 & 0.5 & 13.0 & 3.2 \\
\hline \multirow[t]{4}{*}{2013} & Feb & 0 & 5 & 13.5 & 29.2 & 10.1 & 1.5 \\
\hline & May & 6.0 & 0 & 39.0 & 6.0 & 37.5 & 1 \\
\hline & $\mathrm{Jul}$ & 0 & 2 & 14.6 & 0 & 9.9 & 1.4 \\
\hline & Sep & 0 & 0 & 8.6 & 0 & 7.4 & 2.6 \\
\hline \multirow[t]{3}{*}{2014} & Jan & 88 & 2.5 & 8.5 & - & 7.9 & 1.7 \\
\hline & Mar & 32 & 2.5 & 29.7 & - & 27.0 & 1.7 \\
\hline & May & 0 & 0 & 9.4 & - & 9.1 & 2.5 \\
\hline \multirow[t]{6}{*}{2015} & Jan & 3 & 1 & 1.9 & - & 1.6 & 1.7 \\
\hline & Mar & 6 & 0 & 1.5 & - & 1.5 & 0.8 \\
\hline & May & 16 & 7.5 & 9.2 & - & 8.9 & 2.5 \\
\hline & Jul & 0 & 7.5 & 5.4 & - & 3.7 & 2.6 \\
\hline & Oct & 0 & 1 & 66.2 & - & 60.1 & 1.0 \\
\hline & Nov & 0 & 2.5 & 6 & - & 5.3 & 3.2 \\
\hline \multirow[t]{6}{*}{2016} & Jan & 0 & 2.5 & 1.7 & - & 1.6 & 3.0 \\
\hline & Mar & 0 & 1 & 4.5 & - & 3.7 & 3.5 \\
\hline & May & 0 & 7.5 & 8.5 & - & 7.7 & 2.8 \\
\hline & Jul & 0 & 5 & 9.9 & - & 6.9 & 2.0 \\
\hline & Sep & 0 & 1 & 4.0 & - & 3.1 & 3.5 \\
\hline & Nov & 0 & 7.5 & 7.6 & - & 5.8 & 2.6 \\
\hline \multirow[t]{4}{*}{2017} & Mar & 4160 & $\mathbf{0}$ & 72.1 & - & 63.6 & 1.0 \\
\hline & May & 0 & 0 & 4.7 & - & 2.7 & 7.5 \\
\hline & Jul & 0 & 2.5 & 30 & - & 27.8 & 1.8 \\
\hline & Nov & 0 & 1 & 1.5 & - & 1.4 & 1.9 \\
\hline \multirow[t]{3}{*}{2018} & Jan & 0 & 2.5 & 1.8 & - & 1.5 & 4.0 \\
\hline & Mar & 0 & 7.5 & 6.4 & - & 4.7 & 4.4 \\
\hline & May & 32 & 0 & 34.2 & - & 25.2 & 1.2 \\
\hline
\end{tabular}

U. pen, Unruhdinium penardii; depth, sampling water depth; Chla, maxima chlorophyll $a$; U. pen WA, U. penardii weighted density; Chla WA, weighted chlorophyll $a$; disc, Secchi disc. 
the same station of water samples in May 2013. Sediment samples were processed following the methods reported in Satta et al. (2014), using filtered deionized water instead of filtered seawater. The resulting sample was counted in a $3-\mathrm{mL}$ sedimentation chamber with a Zeiss Axiovert 10 inverted microscope at 400x magnification. Cyst photographs were taken with a Zeiss Axiocam (Carl Zeiss, Oberkochen, Germany). Cyst measurements were obtained from the photographs using the ImageJ software $(1.47 \mathrm{v}$; W. Rasband, USA). Cyst abundances were expressed as the number of cysts per gram dry weight of sediment. Dry weight (DW) was obtained by drying wet sediment subsamples $\left(2-3 \mathrm{~cm}^{3}\right)$ at $105^{\circ} \mathrm{C}$ for $24 \mathrm{~h}$. Germination experiments were conducted in order to identify Unruhdinium penardii cysts. Single cysts and 1 $\mathrm{mL}$ of the sieved (100-10 $\mu \mathrm{m}$; as described in Satta et al., 2014) sample were placed in tissue culture multiplates filled with the abovementioned culture medium. The plates were incubated at $12 \pm 1^{\circ} \mathrm{C}$, with 10 :14 light:dark cycle, under an irradiance of $100 \mu \mathrm{mol} \mathrm{m}{ }^{-2} \mathrm{~s}^{-1}$. Plates were verified every $2-4$ days to check cyst germination.

\section{Strain origin and morphological and molecular characterization of vegetative cells}

Six Unruhdinium penardii strains (from Upen1_Uniss to Upen6_Uniss) were obtained from water samples collected in March 2017. The strains were cultured at a temperature of $12 \pm 1^{\circ} \mathrm{C}$ with an approximate illumination of $100 \mu \mathrm{mol}$ photons $\mathrm{m}^{-2} \mathrm{~s}^{-1}$ and a photoperiod of $10: 14 \mathrm{~h}$ light:dark (L:D). The cells were grown and maintained in L1-Si medium (Guillard and Hargraves, 1993) prepared with filtered deionized water and supplemented by a soil extract (Watanabe, 2005).

The morphology of living and fixed cells from cultures and from the field was determined using Axiovert 100 and Axiovert 10 (Carl Zeiss) inverted microscopes equipped with epifluorescence and differential interference contrast optics. Light microscopic (LM) examination of the thecal plate tabulation was performed on fixed cells (Lugol's iodine, 1\% final concentration) stained with Calcofluor white (Fritz and Triemer, 1985). Chloroplast autofluorescence was examined in live cells. The shape and location of the nuclei were determined after staining $2 \%$ formalin-fixed cells for $10 \mathrm{~min}$ with 4'-6-diamidino-2-phenylindole (DAPI).

LM photographs were taken with a Zeiss Axiocam (Carl Zeiss; Axiovert 10) and a Spot Flex digital camera Spot imaging (Sterling Heights, MI, USA; Axiovert 100). Living and fixed cells from cultures and from the field were also observed under Scanning Electron Microscopy (SEM). Cells were filtered into a 3.0-5.0 $\mu \mathrm{m}$ polycarbonate filter, and washed in distilled water for 15 min. A subsequent dehydration was carried out in a 25 , $50,75,90,95$, and $100 \%$ ethanol series for ca. $10 \mathrm{~min}$. The final step of $100 \%$ ethanol was repeated twice. The filters were critical-point dried in liquid $\mathrm{CO}_{2}$ using a Polaron Jumbo (Quorum Technologies Ltd, Laughton, England) critical-point drying apparatus. The dried filters were then mounted on stubs, sputter coated with goldpalladium and viewed under a SEM Zeiss-EVO (Carl Zeiss, Oberkochen, Germany). SEM micrographs were presented on a black background using Adobe Photoshop 6.0 (Adobe Systems, San Jose, CA, USA). Cell size from cultured and wild fixed material was determined at 400x microscopic magnification using a calibrated eyepiece micrometer and from the LM and SEM photographs using the ImageJ software $(1.47 \mathrm{v})$.

Genomic DNA of the six strains (from Upen1_Uniss to Upen6_Uniss) was extracted from $\sim 15 \mathrm{~mL}$ of exponentially growing cultures. The cells were harvested by centrifugation at 3,000 rpm for $15 \mathrm{~min}$. The pellet was transferred to a $2-\mathrm{mL}$ microcentrifuge tube and centrifuged at $10,000 \mathrm{rpm}$ for $5 \mathrm{~min}$. Total genomic DNA was extracted from the final pellet using the UltraClean Microbial DNA Isolation kit (Mo Bio Laboratories, Inc., Carlsbad, CA, USA), following the manufacturer's instructions.

PCR amplifications followed standard protocols that are described in detail in Satta et al. (2020). Briefly, for SSU and LSU rDNA, a first PCR was conducted to amplify the region of interest using EukA-EukB (Medlin et al., 1988) and D1R-D2C (Scholin et al., 1994) primers respectively. The PCR products were used as a template for a subsequent nested PCR to obtain the dinoflagellate SSU rDNA sequence, using Dino18SF1-18ScomR1 primers (Lin et al., 2006; Zhang and Lin, 2005), the endosymbiont diatom SSU rDNA sequence, using DiaF-DiaR primers (Zhang et al. 2011), and the dinoflagellate LSU rDNA sequence using DinFi-DinRi primers (Logares et al., 2007). The ITS region was directly amplified using ITSA-ITSB primers (Adachi et al., 1994). Purification and Sanger sequencing were conducted by an external service (Genoscreen, Lille, France). The lengths of the sequences obtained were approximately 1,750 bp (SSU rDNA), 550 bp (LSU rDNA), 520-650 bp (ITS) and 1,400 bp (endosymbiont SSU rDNA). The GenBank accession numbers are: MW194105 MW19410 (SSU rDNA), MW194984 - MW194988 (ITS) and MW195006 - MW195011 (LSU rDNA) and MW217557 - MW217562 (endosymbiont SSU rDNA). The sequences generated in this study were aligned with sequences obtained from GenBank belonging to the genus Unruhdinium, Kryptoperidiniaceae representatives, and other dinoflagellate species used as outgroups. The dataset for each sequenced rDNA region was aligned separately using MAFFT v. 7 (Katoh et al., 2002) and manually verified using Geneious v. R6 (Biomatters Ltd., New Zealand). The SSU and LSU rDNA datasets were trimmed using TrimAL (Capella-Gutiérrez et al., 2009). The ITS dataset, which is less conserved than previous regions, was trimmed using Gblocks v0.91b (Castresana 2000) using less 
stringent parameters to avoid an excessive shorten of the alignment. For the endosymbiont sequences obtained, a dataset was constructed including available Unruhdinium endosymbiont sequences and Stephanodiscaceae diatoms sequences following Čalasan et al. (2018) and aligned as previously described.

The resulting alignments had 1695 (SSU rDNA), 611 (ITS), 607 (LSU rDNA) and 1432 (endosymbiont SSU rDNA) positions. Phylogenetic analyses were performed for each region using maximum likelihood (ML) and Bayesian approaches. For the ML tree, the MPI version of RAxML (Randomized Axelerated Maximum Likelihood; Stamatakis 2014) was used. The best-fit model of nucleotide substitution was estimated using jModelTest 2 (Darriba et al., 2012). For all four alignments, the GTR model with a GAMMA distribution was selected, as it showed the best likelihood score (LSU and SSU rDNA), or not significantly different than the best one (ITS, endosymbiont SSU rDNA). The most likely tree was established from 1,000 searches. The ML bootstrap support (BS) was analyzed with 1,000 replicates. The Bayesian analysis was carried out with MrBayes v. 3.2 (Ronquist et al., 2012) using the same evolutionary model, four MCMC chains and 1,000,000 generations. The consensus tree was obtained from post burn-in trees. Statistical support was evaluated by calculating the bootstrap values (\%BS), and Bayesian posterior probabilities (BPP) for all tree topologies.

\section{Statistical analyses}

Interactions between Unruhdinium penardii data and the available environmental variables were analysed applying Generalized Linear Models (GLMs). U. penardii observations in field samples were transformed to binary data (presence/absence) consequently the logit-link function for binomial distribution was applied (McCullagh and Nelder, 1989). A first model was conducted on the basic presence/absence set of data. A second one was realized using an arbitrary threshold of $U$. penardii cell density set at $5 \times 10^{4}$ cells $\mathrm{L}^{-1}$. The fixed terms (predictor variables) of GLMs were the water collection depth layer (water depth), Temp, Cond, $\mathrm{P}-\mathrm{PO}_{4}, \mathrm{TP}, \mathrm{N}-\mathrm{NO}_{3}, \mathrm{~N}_{-} \mathrm{NH}_{4}, \mathrm{~N}-$ $\mathrm{NO}_{2}$ and $\mathrm{TN}$.

Analyses were performed in the statistical and programming software $\mathrm{R}$ version 3.3.3 using the package stats (R Development Core Team, 2017).

\section{RESULTS}

\section{Morphological characterization of vegetative cells and cysts}

Vegetative cells from field samples and cultures showed a conical epitheca and a hypotheca from conical to rounded (Fig. 2 A,B). Cell length and width ranged from 25 to $42.5 \mu \mathrm{m}$ (mean of $31.4 \mu \mathrm{m} \pm 4.5, \mathrm{n}=20$ ) and from 23.8 to $35 \mu \mathrm{m}$ (mean of $29.3 \mu \mathrm{m} \pm 3.9, \mathrm{n}=20$ ), respectively. The observations in LM showed the presence of two-three more or less prominent spines (Fig. 2 A-C) and further shorter spines around the hypothecal plate borders (Fig. 2 D,E). A distinct eyespot was observed in the sulcal area (Fig. 2C). Chloroplasts were numerous and discoid in shape (Fig. 2F). Nuclear staining with DAPI showed the presence of two rather equal in size, rounded nuclei in equatorial position, one of which clearly showing condensed chromosomes (dinokarion) (Fig. 2G).

The plate formula was $\mathrm{Po}, \mathrm{x}, 4$ ', $0 \mathrm{a}, 6$ ", 5C, 5S, 5"' and 2" (Fig. 3 A-G). Theca ornamentation consisted in numerous scattered pores (Fig. 3 A-D). Moreover, numerous cells also showed an irregular vermicular ornamentation (Fig. 3 A,D,E,G). The apical pore complex (APC) was fairly in the centre of epitheca, showing two protruded rims on its sides (Fig. 3 A,B,D). The pore plate (Po) and the canal plate (x) formed the APC (Fig. 3B). Po was comma-shaped, $1.6 \pm 0.1 \mu \mathrm{m}$ long $(\mathrm{n}=8)$, with the upper edge oriented towards the right side of the cell. The $\mathrm{x}$ canal was rectangular and $1.7 \pm 0.2 \mu \mathrm{m}$ long $(\mathrm{n}=8)$.

The apical plate series was symmetrical, without intercalary plate (Fig. 3B). The first apical plate (1') was pentagonal and contacted to APC, the fifth cingular plate (C5) and the sulcal anterior plate (Sa) (Fig. 3A). The 3' plate was six sided (Fig. 3B). The precingular plates (from 1" to 6") were four or five-sided (Fig. 3 B,C). The cingulum was descending, displaced 1 time its width and provided of thorny rims more or less protruded (Fig. $3 \mathrm{~A}$, D). There were 5 cingular plates, of which $\mathrm{C} 1$ was the narrowest (Fig. 3A). Five plates formed the sulcus (Fig. $3 \mathrm{E})$ : the sulcal anterior plate $(\mathrm{Sa})$, the posterior sulcal plate $(\mathrm{Sp})$, the right sulcal plate $(\mathrm{Sr})$, the left sulcal plate (S1) and the median sulcal plate $(\mathrm{Sm})$. Sa was the smallest, whereas Sp the largest (Fig. 3A). Sr was elongated and supported a sulcal list. S1 and Sm were slightly smaller than $\mathrm{Sr}$ and they were both almost hidden by the Sr list (Fig. 3E). A ventral pore was visible at the base of Sa (Fig. 3A). The two antapical plates (1"', and 2 "',) were rather centred with respect to the five postcingular plates $(1 ",-5 "$ ") and the Sp (Fig. 3G). The antapical plates supported a series of spines (Fig. 3G). The most prominent spines ranging from 0.7 to $1.8 \mu \mathrm{m}$ in length $($ mean $=1.2 \pm 0.3 \mu \mathrm{m}, \mathrm{n}=20)$ were located along the edges adjacent to the sulcal area (Fig. 3 A,E). This type of ornamentation, although less prominent, was also present along the postcingular plates (Fig. 3 A, E-G). Cysts were oval in shape, 29.6 $\pm 2.2 \mu \mathrm{m}$ long and 28.7 \pm 2.2 $\mu \mathrm{m}$ wide $(\mathrm{n}=11)$. The cyst content was grainy with yellowish to reddish accumulation bodies (Fig. 4 A,B). Most of the cysts maintained the external theca (Fig. 4A). Cysts with theca were more abundant in the sediments 

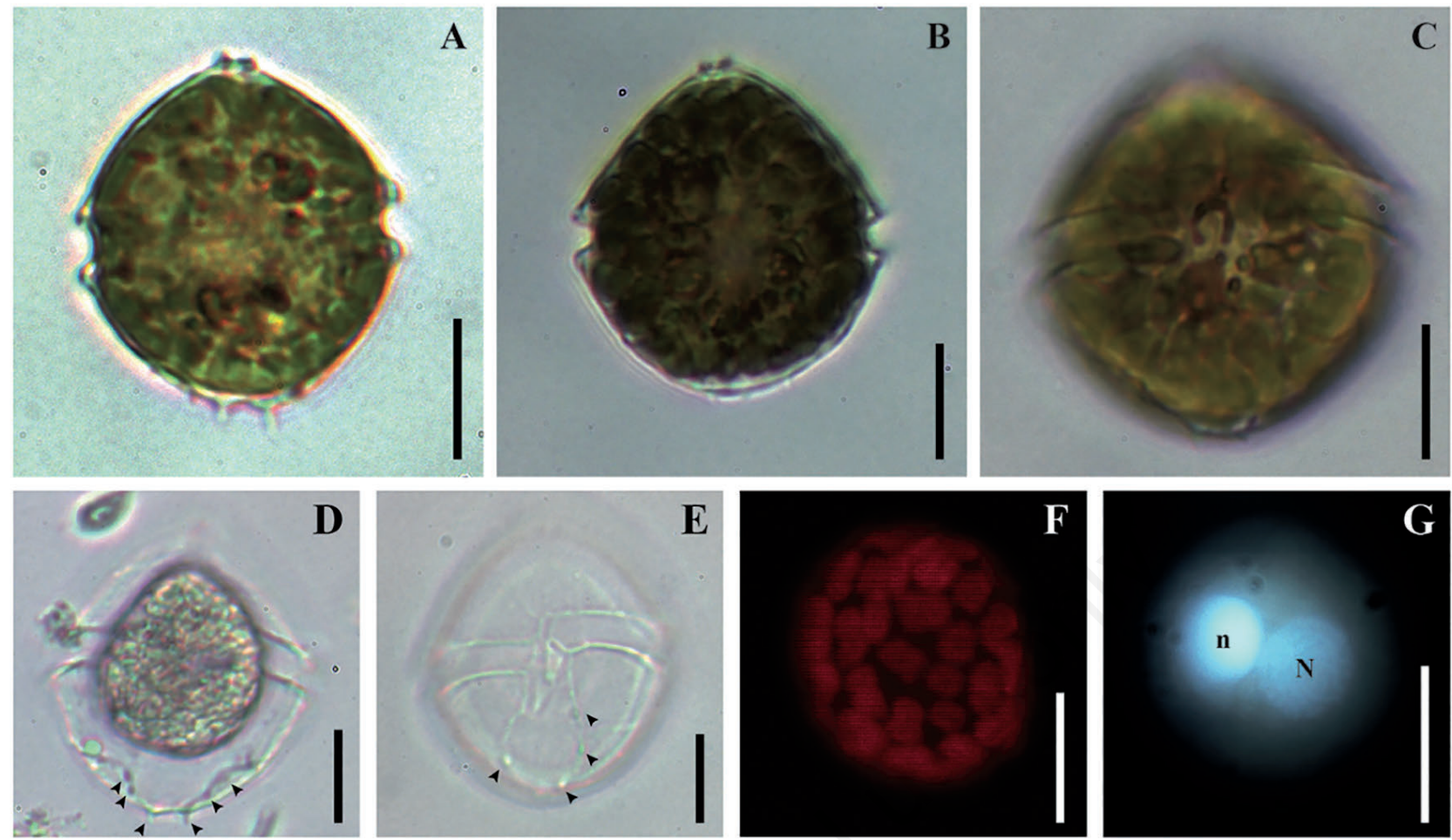

Fig. 2. Morphology of Unruhdinium penardii cells in light and epifluorescence microscopy from the Cedrino Lake (Sardinia, Italy). A,B) Ventral and dorsal view of alive cells (A-B); C) eyespot localization; D,E) hypothecal spines arrangement; F) shape of chloroplasts; $\mathrm{G})$ position of the nuclei, showing the dinokarion $(\mathrm{N})$ and the diatom nucleus $(\mathrm{n})$. Scale bars: $10 \mu \mathrm{m}$.

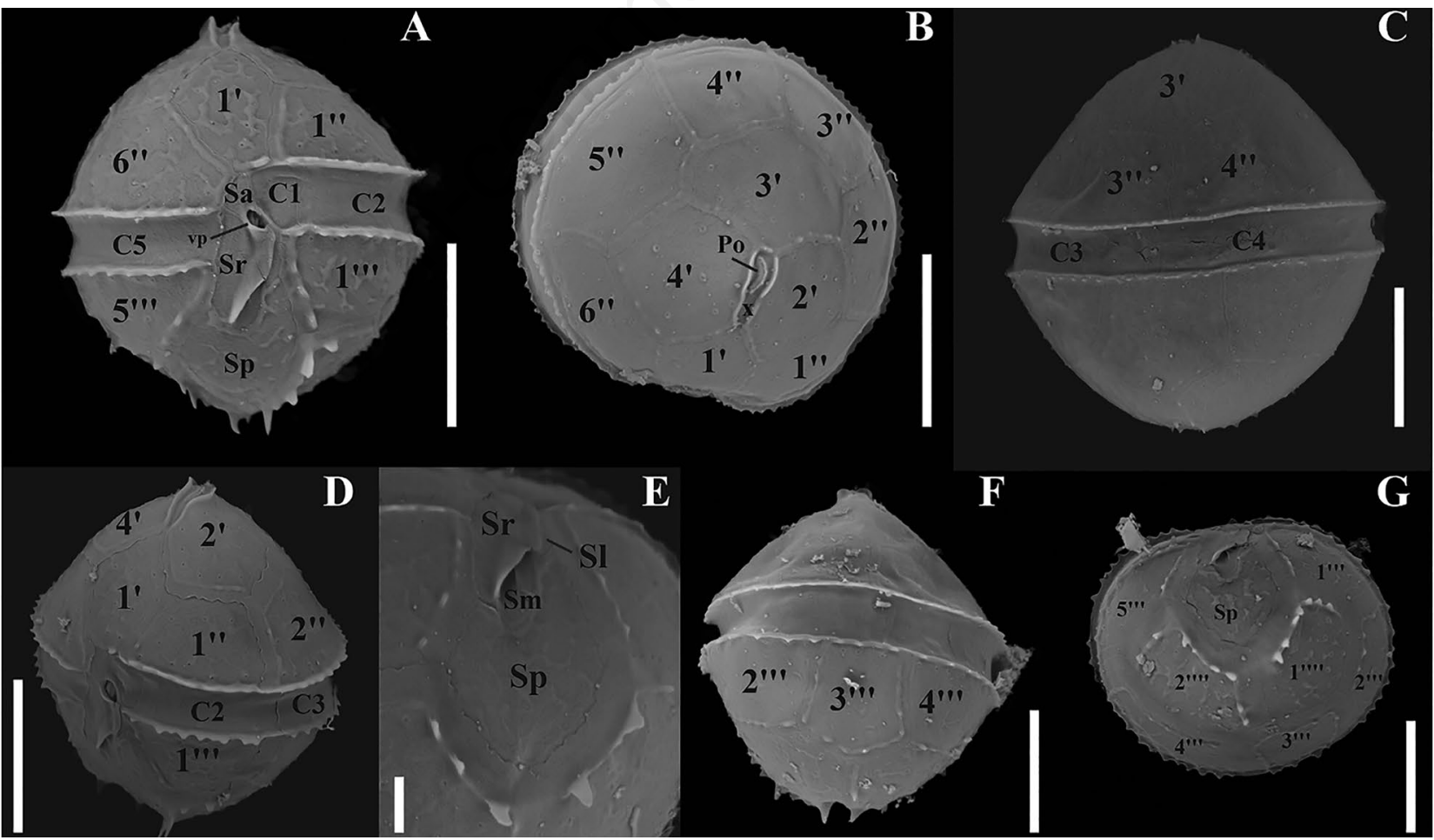

Fig. 3. Scanning electron micrographs showing the tabulation of Unruhdinium penardii from the Cedrino Lake (Sardinia, Italy): ventral view (A), apical view showing the APC structure (B), dorsal view (C), latero-apical view (D), sulcal plates arrangement (E), dorsal view showing the dorsal post cingular plates $(\mathrm{F})$, and antapical view $(\mathrm{G})$. Scale bars represent $10 \mu \mathrm{m}$ for A-D and F-G. Scale bar of E represents $2 \mu \mathrm{m}$. 


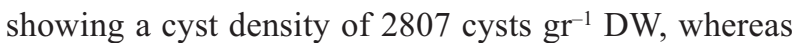
the other smooth, oval cysts were detected at a cyst density of 792 cysts gr $^{-1} \mathrm{DW}$.

The incubation of sieved sediment samples produced Unruhdinium penardii vegetative cells. The single-cyst germination experiments were unsuccessful.

\section{Molecular characterization}

All six cultured strains produced almost identical sequences for the three rDNA regions analysed $(99.8 \%$ pairwise identity for SSU rDNA sequences, $100 \%$ for LSU rDNA and $99.8 \%$ for ITS rDNA, respectively). Most differences were found related to polymorphic positions. For SSU rDNA phylogeny (Fig. 5), a cluster including all Kryptoperidiniaceae members, i.e. Galeidinium, Kryptoperidinium, Durinskia, Blixaea and Unruhdinium genera, was obtained with moderate/high support (88\%/1). Sequences representing Unruhdinium species formed a highly supported clade $(99 \% / 1)$. Sequences from this study clustered with $U$. penardii sequences available from China (HM596543) and Japan (AB353771), even though under moderate support $(73 \% / 0.96)$. The sequence available for $U$. niei (Liu et $\mathrm{Hu}$ ) Gottschling was at the base of this cluster, and the sequences of $U$. minimum (Zhang, Liu et $\mathrm{Hu}$ ) Gottschling, $U$. cf. kevei and $U$. jiulongensis clustered independently. The same phylogenetic relationships were obtained for ITS (Supplementary Fig. 1) and LSU rDNA (Supplementary Fig. 2), with all Unruhdinium sequences forming a wellsupported clade $(97 \% / 1$ for ITS and $94 \% / 1$ for LSU rDNA). The sequences from this study clustered with $U$. penardii sequences available from China $(100 \% / 1$ for ITS, 92\%/- for LSU rDNA). The sequence available for U. penardii var. robustum (Zhang, Liu et $\mathrm{Hu}$ ) Gottschling clustered at the base of the previous clade $(85 \% / 0.98)$ in the ITS phylogeny, and $U$. niei sequences forming a sister branch (-/0.93). For the LSU rDNA phylogeny, the $U$. penardii var. robustum sequence formed a sister branch

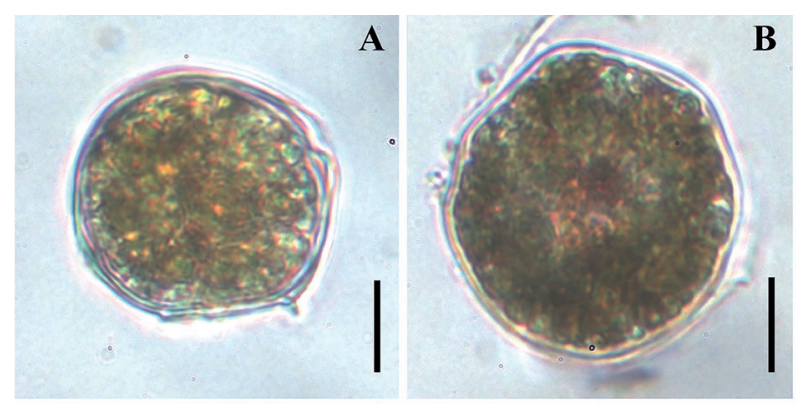

Fig. 4. Morphology of Unruhdinium penardii cysts in light microscopy from the Cedrino Lake (Sardinia, Italy): cyst with theca (A) and without theca (B). Scale bars: $10 \mu \mathrm{m}$. with $U$. niei sequences (-/0.99) clustering with $U$. penardii sequences $(78 \% / 0.99)$. In both phylogenies, sequences of $U$. jiulongensis and $U$. minimum clustered more distantly.

For the endosymbiont SSU rDNA, all sequences were also almost identical $(99.7 \%$ pairwise identity) and differences corresponded to polymorphic positions. The constructed phylogeny (Supplementary Fig. 3) showed the sequences obtained were included in a well-supported cluster $(95 \% / 1)$ containing all the endosymbiont sequences available for Unruhdinium representatives, together with the diatoms Discostella/Cyclotella. However, the genetic distance between members of the clade was low, resulting in several polytomies in internal branches and the relationships within this cluster were not well resolved. The sequences from this study clustered with sequences corresponding to $U$. cf. kevei and $U$. jiulongensis endosymbionts and two Discostella/Cyclotella sequences, but showing no statistical support $(72 \% /-)$. Instead, available $U$. penardii endosymbiont sequences clustered together with Discostella nipponica in a sister clade, but again showing moderate statistical support (89\%/-). Polymorphic positions detected in the generated sequences mostly coincided with the differences between sequences available for $U$. penardii and $U$. cf. kevei endosymbionts, resulting in the observed topology.

\section{Unruhdinium penardii dynamic and relationship with the environmental conditions along the study period}

Unruhdinium penardii was detected in a wide seasonal time-frame (from December to June), embracing winter-cold and spring-mild months. On the contrary, its blooms were limited to a restricted seasonal period (February-March; Tab. 1). U. penardii specimens were prevalently recorded in more surface samples (from 0 to $2.5 \mathrm{~m}$ ). The three most relevant bloom events accompanied by reddish water discolorations were detected, in March 2011, February 2012 and March 2017 (Tab. 1). The highest cell density was recorded in February $2012\left(25.6 \times 10^{6}\right.$ cells L $\left.^{-1}\right)$.

During the bloom events, Chla values were among the highest found in the sampling period (maximum of 360 $\mathrm{mg} \mathrm{m}^{-3}$ in the surface sample, in February 2012; Tab. 1). The three bloom events corresponded to late winter-early spring environmental conditions in Cedrino Lake (Supplementary Tab. 2). Temp values ranged from 11.1 ${ }^{\circ} \mathrm{C}$ to $15{ }^{\circ} \mathrm{C}$, Cond values from $313 \mu \mathrm{S} \mathrm{cm}$ co $^{-1}$ to $349 \mu \mathrm{S}$ $\mathrm{cm}^{-1}$ and the lake was in mixing (Supplementary Tab. 2). Nutrient concentrations revealed values among the lower of the entire dataset for $\mathrm{P}_{-} \mathrm{PO}_{4}$ and intermediate for TP and DIN (Supplementary Tab. 2).

The first GLM regression revealed that Temp and Cond had significant effects on the presence of Unruhdinium penardii along the study period (Tab. 2). The second GLM regression showed a significant effect 
of water depth, Temp and $\mathrm{P}-\mathrm{PO}_{4}$ on the presence of the species at the highest cell densities (Tab. 2).

\section{DISCUSSION}

Data collected in this study contribute to increase the information on the ecology, morphology and phylogeny of Unruhdinium penardii. This work signals for the first time in a Mediterranean reservoir, its well-established presence and its bloom forming behaviour. The collection of new morphological and molecular data is particularly of interest for freshwater dinoflagellates, many of which were described before electron microscopy and molecular genetic methods became available (Annenkova, 2013). In addition, deepening the knowledge on the ecology of bloom-forming dinoflagellate species can be useful to manage events that may adversely affect water quality in Mediterranean reservoirs, especially for their strategic role as drinking water resources in this semi-arid climate region (Mariani et al., 2015).

\section{Morphology and phylogeny}

In recent years, the combination of morphological and genetic studies allowed to identify and delineate the main characteristics of the peculiar freshwater dinoflagellates now included in the genus Unruhdinium, formerly

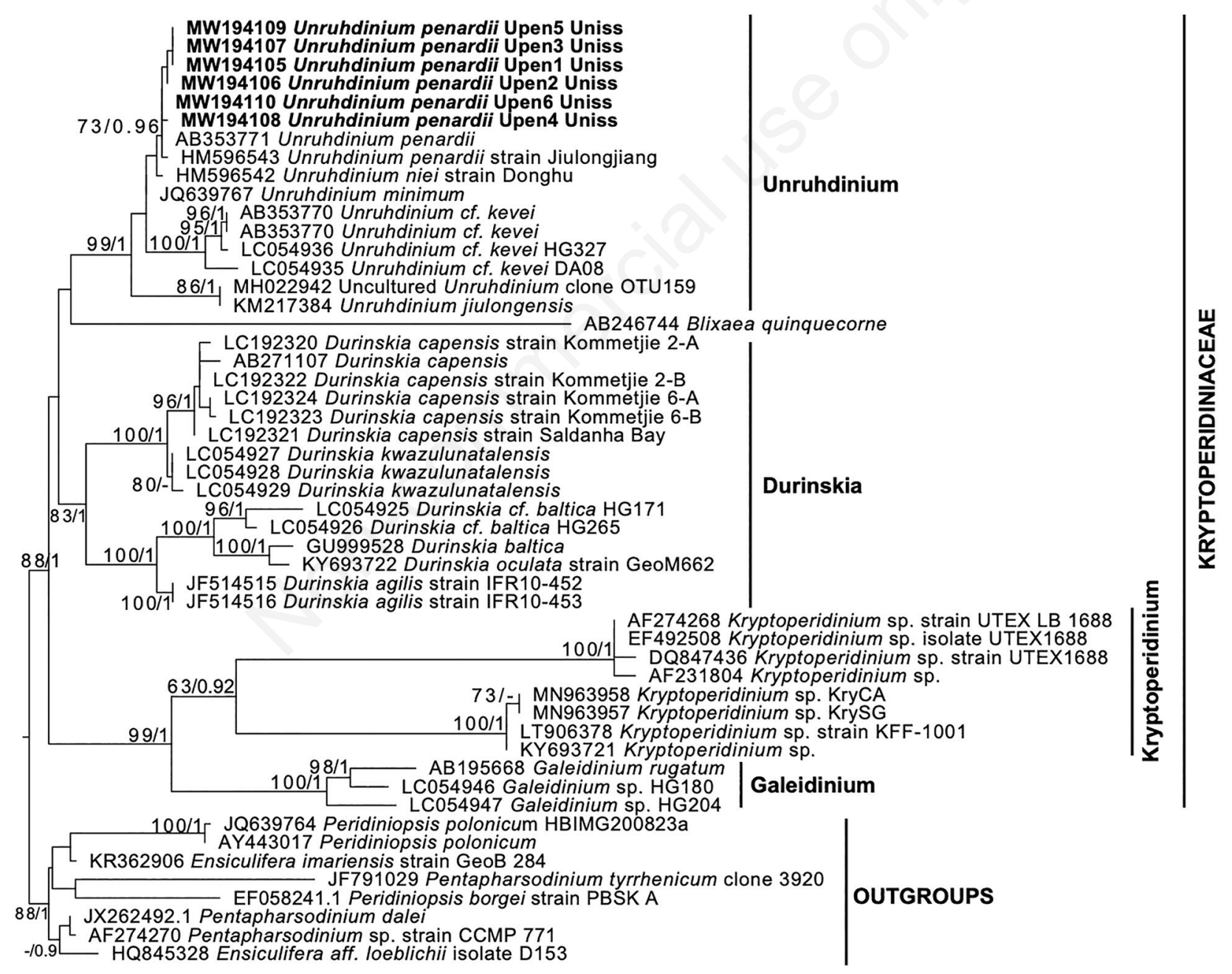

0.008

Fig. 5. Maximum likelihood phylogenetic tree inferred from the SSU rDNA sequences, including representatives of the family Kryptoperidiniaceae and other sequences used as outgroups. Unruhdinium penardii sequences obtained in this study are indicated in bold. The bootstrap values (BP) and the Bayesian posterior probabilities (BPP) are provided at each node (\% BS/BPP). Only BS and BPP values $>70 \%$ and $>0.90$ are shown. 
ascribed to Peridiniopsis (Gottschling et al., 2017). These new data derived from the description of new species (Zhang et al., 2014; You et al., 2015) and from insights on known species (Takano et al., 2008; Zhang et al., 2011) underlining the growing interest and study effort on freshwater dinoflagellates belonging to the Kryptoperidiniaceae family. Following the collected morphological information, other dinoflagellates previously ascribed to the genus Peridiniopsis were also recently included in the genus Unruhdinium ( $U$. armebeense and $U$. durandii (Rodriguez, Couté, TenHage et Mascarell) Moestrup et Calado; Moestrup and Calado, 2018). Morphological and molecular data obtained in this study allowed the determination of the species U. penardii from the field samples and from cultures of Cedrino Lake. Consequently, data reported in this study are the first obtained on U. penardii from the Mediterranean area.

$U$. penardii from Cedrino Lake showed a prominent apical pore complex, clearly visible also in LM, four apical plates, no epithecal intercalary plates, five cingular plates and two or three antapical spines. This thecal plate pattern coincided with the recent published observations (Hansen and Flaim, 2007; Takano et al., 2008; Zhang et al., 2011, 2013). The presence of additional shorter spines along the antapical plate borders was not reported prior to this study, although Hansen and Flaim (2007) described the presence of small antapical spines in their material. Spine lengths in the Cedrino Lake material were variable (maximum length of $1.8 \mu \mathrm{m}$ ) and spines were sometimes

Tab. 2. Results of the generalized linear models (GLMs) applied on selected environmental variables and on 1) the absence/presence data of Unruhdinium penardii and 2) the absence/presence data using an arbitrary threshold of $U$. penardii cell density set at $5 \times 10^{4}$ cells $\mathrm{L}^{-1}$. Significant effects are shown in bold.

\begin{tabular}{|c|c|c|c|c|}
\hline \multicolumn{5}{|c|}{1 GLM - absence/presence } \\
\hline & Estimate & Standard error & $\mathrm{Z}$ value & $\operatorname{Pr}(>\mathbf{Z})$ \\
\hline (Intercept) & 10.68 & 2.73 & 3.91 & $<0.0001$ \\
\hline depth & -0.06 & 0.06 & -1.09 & 0.28 \\
\hline Temp & -0.37 & 0.09 & -4.35 & $<0.0001$ \\
\hline Cond & -0.01 & 0.01 & -2.09 & $<0.05$ \\
\hline $\mathrm{P}-\mathrm{PO}_{4}$ & -0.03 & 0.02 & -1.69 & 0.09 \\
\hline \multicolumn{5}{|c|}{2 GLM - absence/presence (threshold: $5 \times 10^{4}$ cells L ${ }^{-1}$ ) } \\
\hline & Estimate & Standard error & $\mathrm{Z}$ value & $\operatorname{Pr}(>\mathbf{Z})$ \\
\hline (Intercept) & 81.67 & 34.86 & 2.34 & $<0.05$ \\
\hline depth & -0.80 & 0.39 & -2.04 & $<0.05$ \\
\hline Temp & -3.98 & 1.82 & -2.17 & $<0.05$ \\
\hline Cond & -0.08 & 0.05 & -1.67 & 0.09 \\
\hline $\mathrm{P}-\mathrm{PO}_{4}$ & -0.54 & 0.23 & -2.31 & $<0.05$ \\
\hline
\end{tabular}

Depth, sampling water depth; Temp, water temperature; Cond,

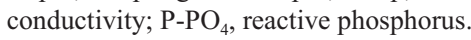

difficult to be observed in LM. The presence of small antapical spines differentiated the specimens from Cedrino Lake from those of $U$. penardii var robustum, whose morphological description indicated a large number of rather prominent spines (mean length: $2.8 \mu \mathrm{m}$; Zhang et al., 2011). The other two characteristics already found in $U$. penardii and also observed in the cells from Cedrino Lake were the presence of an eyespot and a second eukaryotic nucleus.

The morphological features of $U$. penardii (especially cell shape, size and presence of antapical spines) appeared to be quite specific in respect to the other Unruhdinium species. On the contrary, these features were shared with $U$. durandii morphology. The main differences between the two species appeared to be the shape of the cell (ovoid in $U$. penardii and rhomboid in $U$. durandii) and the ornamentation of the plates (clearly reticulated in $U$. durandii). However, Hansen and Flaim (2007) reported a certain variability in $U$. penardii cell shape (from ovoid to rhomboid) and plate ornamentation (from smooth to slightly reticulated surface) suggesting $U$. durandii as junior synonymous of $U$. penardii. The cells from Cedrino Lake showed certain variability in the shape of the cells and a pseudo-reticulated ornamentation of the thecal plates. In addition, the distribution pattern of $U$. durandii spines and their lengths (maximum of $2 \mu \mathrm{m}$; Rodriguez et al., 1999) matched with the observations obtained in this study. Further data from the type locality of $U$. durandii are certainly needed to completely understand and describe the relationship between these two species. $U$. penardii cysts from Cedrino Lake sediments were oval in shape resembling those described by Sako et al. (1987) from cultures. However, the most abundant cysts retained the theca, therefore closely resembling vegetative cells. Similar benthic stages were described for Blixaea quinquecornis (Abé) Gottschling (as Peridinium quinquecorne; Satta et al., 2010), Bysmatrum subsalsum (Ostenfeld) Faust et Steidinger (Anglès et al., 2017) and from other both planktonic and benthic dinoflagellate species (Bravo and Figueroa, 2014 and references therein). The role and the origin of these 'thecate cysts' have yet to be investigated.

Unruhdinium penardii sequences from Cedrino Lake were identical or really close ( $>99.5 \%$ similarity) to those from Chinese and Japanese isolates. While some of the genetic markers used in this study, i.e., SSU rDNA, correspond to conserved regions, LSU rDNA and ITS regions are considered as more variable, and have been commonly used to determine intraspecific variability and speciation processes in dinoflagellates (Penna et al., 2008; Lin et al., 2020). The ITS sequences obtained for $U$. penardii were $100 \%$ identical to those from geographically distant locations (China and Japan), suggesting a low intraspecific genetic variability, even 
though inhabiting isolated environments also very far from each other. The sequences obtained were clearly differentiated from those available for U. penardii var. robustum, in agreement with morphological differences described. In all rDNA regions, the species showed the closest phylogenetic relationship with $U$. niei, rather than the other Unruhdinium species, even though they did not show apparent morphological similarities supporting it. Regarding the phylogenetic relationships of Kryptoperidiniaceae, all sequences formed a wellsupported cluster for all regions, as also observed for the other genera of the family. However, the phylogenetic relationship among the different genera was not resolved. The information retrieved from the diatom endosymbiont SSU rDNA sequences was not conclusive, even though it was in agreement with previous knowledge on the identity of the diatom endosymbiont of Unruhdinium. The low genetic distance found for the different Unruhdinium endosymbiont species and the presence of several polymorphic positions impeded a clear discrimination between $U$. penardii, $U$. cf. kevei and $U$. jiulongensis endosymbionts and to determine their phylogenetic relationships.

\section{Ecology}

Reservoirs are man-made ecosystems assuring important goods and services to local human populations (e.g., they are sources for drinking and irrigation water, energy production, aquaculture exploitation, flood management, touristic and leisure activities; Padedda et al., 2017). Their role as the main source of water supply for human populations was reported to be even more important in semi-arid regions, such as those of the Mediterranean climate (Marcé and Armengol, 2010). Eutrophication was indicated as the main issue impacting on reservoirs (Smith et al., 1999) also in the Mediterranean region (Marchetto et al., 2009). Among the detrimental effects of eutrophication, the occurrence of harmful algal blooms represented a consistent threat, especially for drinking and irrigation uses when the causative organisms were toxic (Codd 2000). Generally, the organisms involved in this kind of events belonged to Cyanobacteria (Paerl and Otten, 2013; Meriluoto et al., 2017). However, dinoflagellates were also frequently reported to cause blooms in reservoir ecosystems causing water discoloration and increase in water turbidity (e.g., Ceratium hirundinella, Lugliè et al., 2001; PérezMartìnez and Sànchez-Castillo, 2001; Fadel et al., 2015; Mariani et al., 2015). Some species belonging to the Unruhdinium genus, including $U$. penardii, were reported as high biomass bloom-forming species often causing dark or reddish water discolorations (Javornický 1972; Leitão et al., 2001; Rodriguez et al., 1999; Hansen and Flaim, 2007; Liu et al., 2008; You et al., 2015). The same typology of events was observed in Cedrino Lake during U. penardii blooms. However, ecological data describing the adverse events are today limited. Field observations collected in this study allowed defining the ecological conditions during the presence of the species and at the highest densities. The species was detected along a fairly large temporal period (about coinciding with the first semester of the year) but it was never detected in summer. Blooms exhibited strong seasonality restricted to the late winter and early spring months (February and March). GLMs revealed the significant role of temperature on $U$. penardii presence and blooms in the Cedrino Lake, underlining a preference of this species for colder months. The same seasonal behaviour was reported for U. niei in Lake Donghu (Liu et al., 2008). In the Cedrino Lake, $U$. penardii produced blooms in a temperature range between $11.1^{\circ} \mathrm{C}$ and $15^{\circ} \mathrm{C}$, whereas the same species was reported to bloom at lower temperature in the Black Sea (Terenko 2017). U. durandii in the Voiglans reservoir (Rodriguez et al., 1999) showed the same temperature bloom range of $U$. penardii in the Cedrino Lake.

Investigating the role of nutrients is a challenge and must takes in consideration the possible mixotrophy of dinoflagellates in freshwater ecosystems (e.g., Carrias et al., 2001; Tardio et al., 2003; Pålsson and Granéli, 2004). Anyway, the Cedrino Lake showed a high nutrient availability being classified from eutrophic to hypereutrophic (Padedda et al., 2015, 2017). Data from the present study revealed a significant association of $U$. penardii with low phosphate values, especially during blooms. Kawabata and Hirano (1995) observed a reduction of the cellular phosphorus content during the growth of $U$. penardii in the Ishitegawa Reservoir, hypothesizing a use of the stored phosphorus during the population growth phase. Maximum cell densities of $U$. penardii in the Cedrino Lake could be indirectly explained by the ability of dinoflagellates to use organic sources of phosphorus (e.g., DOP) as already revealed for U. niei (reported as Peridiniopsis sp.; Cao et al., 2019). These species, in this way, could acquire an advantage over the other phytoplankton species in low phosphate conditions. In addition, a strong significant correlation between Unruhdinium cell density and the phosphatase alkaline activity was demonstrated from the Three Gorges reservoirs (reported as Peridiniopsis sp.; Wu et al., 2018). The same study revealed the ability of the species to migrate in deeper layers during the night in relation to the availability of dissolved organic phosphorus (Wu et al., 2018). Diel vertical migrations of $U$. niei were also in relationship to light radiation (Xu et al., 2010). In fact, maximum cell densities of $U$. niei were recorded during the day and at the surface water layers (Xu et al., 2010). Similarly, $U$. penardii at the highest cell densities in the Cedrino Lake showed a significant inverse relationship 
with water depth as revealed by GLM. Taking into account these observations, further investigations are required to completely understand the dynamics of the $U$. penardii blooms in the Cedrino Lake and to assess the role of the different environmental variables.

In any case, data collected in this study provide a useful base of knowledge for further insights on this harmful species in the Mediterranean area.

\section{CONCLUSIONS}

In the scenario of global climate change underway, the Mediterranean area was indicated as one of the most vulnerable (Erol and Randhir, 2012) and the aquatic resources of this area are reported to be very sensitive to these changes (García-Ruiz et al., 2011). In particular, further water restrictions are expected. The impact of high biomass bloom forming dinoflagellates (as $U$. penardii) could be deleterious in drinking water plants. Numerous species could cause unpleasant taste and odour of water, but also accelerate clogging of filter systems in drinkingwater treatment. They could also break through these filters with the consequence of elevating the dissolved organic carbon (DOC) concentrations of the purified water and thus enhancing microbial growth (Niesel et al., 2007). In this context, acquiring ecological data on potentially harmful species is mandatory in order to be able to manage adverse events maximizing the sustainable use of resources.

\section{ACKNOWLEDGMENTS}

The authors thank Dr. Bastianina Manca and Dr. Pasqualina Farina (University of Sassari) for the nutrient analysis. The activities of Prof. Antonella Lugliè and Dr. Bachisio Mario Padedda were supported by the research fund of the University of Sassari (Fondo di Ateneo per la Ricerca 2019).

Corresponding author: ctsatta@uniss.it

Key words: Peridiniopsis; cultures; temperature; cysts; endosymbiont.

Received: 13 November 2020

Accepted: 10 December 2020.

This work is licensed under a Creative Commons Attribution NonCommercial 4.0 License (CC BY-NC 4.0).

${ }^{\circ}$ Copyright: the Author(s), 2020

Licensee PAGEPress, Italy

Advances in Oceanography and Limnology, 2020; 11:9500

DOI: 10.4081/aiol.2020.9500

\section{REFERENCES}

Adachi M, Sako Y, Ishida Y, 1994. Restriction fragment length polymorphism of Ribosomal DNA internal transcribed spacer and 5.8s- regions in Japanese Alexandrium Species (Dinophyceae). J. Phycol. 30:857-863.

Anglès S, Reñé A, Garcés E, Lugliè A, Sechi N, Camp J, Satta CT, 2017. Morphological and molecular characterization of Bysmatrum subsalsum (Dinophyceae) from the western Mediterranean Sea reveals the existence of cryptic species. J. Phycol. 53:883-847.

Annenkova NV, 2013. Phylogenetic relations of the dinoflagellate Gymnodinium baicalense from Lake Baikal. Centr. Eur. J. Biol. 8:366-373.

Bravo I, Figueroa RI, 2014. Towards an Ecological Understanding of Dinoflagellate Cyst Functions. Microorganisms 2:11-32.

Čalasan AZ, Kretschmann J, Gottschling M, 2018. Absence of co-phylogeny indicates repeated diatom capture in dinophytes hosting a tertiary endosymbiont. Org. Divers. Evol. 18:29-38.

Cao X, Wan L, Xiao J, Chen X, Zhou Y, Wang Z, Song C, 2019. Environmental effects by introducing Potamogeton crispus to recover a eutrophic Lake. Sci. Total Environ. 621:360-367.

Capella-Gutiérrez S, Silla-Martínez JM, Gabaldón T, 2009. trimAl: a tool for automated alignment trimming in largescale phylogenetic analyses. Bioinformatics 25:1972-1973.

Carrias JF, Thouvenot A, Amblard C, Sime-Ngando T, 2001. Dynamics and growth estimate of planktonic protists during early spring in lake Pavin, France. Aquat Microb. Ecol. 24:163-174.

Castresana J, 2000. Selection of conserved blocks from multiple alignments for their use in phylogenetic analysis. Mol. Biol. Evol. 17:540-552.

Codd GA, 2000. Cyanobacterial toxins, the perception of water quality, and the prioritisation of eutrophication control. Ecol. Eng. 16:51-60.

Darriba D, Taboada G, Doallo R, Posada D, 2012. jModelTest 2: more models, new heuristics and parallel computing. Nat Methods 9:772.

Fadda A, Manca M, Camin F, Ziller L, Buscarinu P, Mariani MA, Padedda BM, Sechi N, Virdis T, Luglie A, 2016. Study on the suspended particulate matter of a Mediterranean artificial lake (Sos Canales Lake) using Stable Isotope Analysis of carbon and nitrogen. Ann. Limnol. Int. J. Limnol. 52:401-412.

Fadel A, Atoui A, Lemaire BJ, Vinçon-Leite B, Slim K, 2015. Environmental factors associated with phytoplankton succession in a Mediterranean reservoir with a highly fluctuating water level. Environ. Monit. Assess. 187:633.

Fritz L, Triemer RE, 1985. A rapid simple technique utilizing Calcofluor White M2R for the visualization of dinoflagellate thecal plates. J. Phycol. 21:662-664.

García-Ruiz JM, López-Moreno JI, Vicente-Serrano SM, LasantaMartínez T, Beguería S, 2011. Mediterranean water resources in a global change scenario. Earth. Sci. Rev. 105:121-139. Goltermann HL, Clymo RS, Ohnstad MAM, 1978. Method for Physical and Chemical Analysis of Fresh Waters. I.B.P. N. 8. Blackwell Scientific Publications, Oxford: 214 pp.

Gottschling M, Calasan AZ, Kretschmann J, Gu H,2017. Two new generic names for dinophytes harbouring a diatom as an endosymbiont, Blixaea and Unruhdinium 
(Kryptoperidiniaceae, Peridiniales). Phytotaxa 306: 296-300.

Guillard RRL, Hargraves PE, 1993. Stichochrysis immobilis is a diatom, not a chrysophyte. Phycologia 32:234-236.

Hansen G, Flaim G, 2007. Dinoflagellates of the Trentino Province, Italy. J Limnol. 66:107-141.

Imanian B, Pombert JF, Keeling PJ, 2011. The complete plastid genomes of the two 'dinotoms' Durinskia baltica and Kryptoperidinium foliaceum. PLoS ONE 5:e10711.

Javornický P, 1972. Peridinium penardii (Lemm.) Lemm. f. californicum, forma nova. J. Phycol. 7:303-306.

Kretschmann J, Calasan AZ, Gottschling M, 2018. Molecular phylogenetics of dinophytes harbouring diatoms as endosymbionts (Kryptoperidiniaceae, Peridiniales), with evolutionary interpretations and a focus on the identity of Durinskia oculata from Prague. Mol. Phylogenetics Evol. 118:392-402.

Leitão M, Ten-Hage L, Mascarell G, Couté A, 2001. Peridiniopsis corillionii sp. nova (Dinophyta), une nouvelle dinophycée d'eau douce de France responsible de marées rouges en rivière. Algol. Stud. 102:1-15.

Lin S, Zhang H, Hou Y, Miranda L, Bhattacharya D, 2006. Development of a dinoflagellate-oriented PCR primer set leads to detection of picoplanktonic dinoflagellates from Long Island Sound. Appl. Environ. Microbiol. 72:5626 -5630.

Lin S, Hu Z, Deng Y, Shang L, Gobler CJ, Tang YZ, 2020. An assessment on the intrapopulational and intraindividual genetic diversity in LSU rDNA in the harmful algal bloomsforming dinoflagellate Margalefidinium (= Cochlodinium) fulvescens based on clonal cultures and bloom samples from Jiaozhou Bay, China. Harmful Algae 96:101821.

Liu GX, Pei GF, Hu ZY, 2008. Peridiniopsis niei sp. nov. (Dinophyceae), a new species of freshwater red tide dinoflagellates from China. Nova Hedwigia 87:487-499.

Logares R, Shalchian-Tabrizi K, Boltovskoy A, Rengefors K, 2007. Extensive dinoflagellate phylogenies indicate infrequent marine-freshwater transitions. Mol. Phylogenetics Evol. 45:887-903.

Marcé R, Armengol J, 2010. Water quality in reservoirs under a changing climate, p. 73-94. In: S. Sabater and D. Barceló (eds.), Water Scarcity in the Mediterranean. Springer, Amsterdam.

Marchetto A, Padedda BM, Mariani MA, Lugliè A, Sechi N, 2009. A numerical index to evaluate the phytoplankton response to changes in nutrient levels in deep Mediterranean reservoirs. J Limnol. 68:106-121.

McCullagh P, Nelder JA, 1989. Generalized Linear Models. Chapman and Hall, London: 512 pp.

Meriluoto J, Blaha L, Bojadzija G, Bormans M, Brient L, Codd GA, Drobac D, Faassen EJ, Fastner J, Hiskia A, Ibelings BW, Kaloudis T, Kokocinski M, Kurmayer R, Pantelić D, Quesada A, Salmaso N, Tokodi N, Triantis TM, Visser PM, Svirčev Z, 2017. Toxic cyanobacteria and cyanotoxins in European waters - recent progress achieved through the CYANOCOST Action and challenges for further research. AIOL 8:161-178.

Medlin L, Elwood HJ, Stickel S, Sogin ML, 1988. The characterization of enzymatically amplified eukaryotic 16Slike rRNA-coding regions. Gene 71:491-499.

Messineo V, Bogialli S, Melchiorre S, Sechi N, Lugliè A, Casiddu
P, Mariani MA, Padedda BM, Di Corcia A, Mazza R, Carloni E, Bruno M, 2009. Cyanotoxins occurrence in Italian freshwaters. Limnologica 39:95-106.

Moestrup Ø, Calado AJ, 2018. Süßwasserflora von Mitteleuropa, Bd. 6 - Freshwater Flora of Central Europe, Vol. 6: Dinophyceae. Springer Spektrum, Berlin: 561 pp.

Niesel V, Hehn E, Sudbrack R, Willmitzer H, Chorus I, 2007. The occurrence of the Dynophyte species Gymnodinium uberrimum and Peridinium willei in German reservoirs. J. Plankton Res., 29:347-357.

Padedda BM, Sechi N, Lai GG, Mariani MA, Pulina S, Satta CT, Bazzoni AM, Virdis T, Buscarinu P, Lugliè A, 2015. A fastresponse methodological approach to assessing and managing nutrient loads in eutrophic Mediterranean reservoirs. Ecol. Eng. 85:47-55.

Padedda BM, Sechi N, Lai GG, Mariani MA, Pulina S, Sarria M, Satta CT, Virdis T, Buscarinu P, Lugliè A, 2017. Consequences of eutrophication in the management of water resources in Mediterranean reservoirs: A case study of Lake Cedrino (Sardinia, Italy). Glob. Ecol. Conserv. 12:21-35.

Paerl HW, Otten TG, 2013. Harmful cyanobacterial blooms: causes, consequences, and controls. Microb. Ecol. 65: 995-1010.

Pålsson C, Granéli W, 2004. Nutrient limitation of autotrophic and mixotrophic phytoplankton in a temperate and tropical humic lake gradient. J. Plankton Res. 26:1005-1014.

Penna A, Fraga S, Masó M, Giacobbe MG, Bravo I, Garcés E, Vila M, Bertozzini E, Andreoni F, Lugliè A, Vernesi C, 2008. Phylogenetic relationships among the Mediterranean Alexandrium (Dinophyceae) species based on sequences of 5.8S gene and Internal Transcript Spacers of the rRNA operon. Eur. J. Phycol. 43:163-178.

Pérez-Martinez C, Sánchez-Castillo P, 2002. Winter dominance of Ceratium hirundinella in a Southern north-temperate reservoir. J. Plankton Res. 24:89-96.

Poikane S, 2009. Water Framework Directive intercalibration technical report. Part 2:Llakes. JRC Scientific and Technical Reports. European Commission, Luxembourg: 176 pp.

Rodriguez S, Couté A, Ten-Hage L, Mascarell G, 1999. Peridiniopsis durandi sp. nova (Dinophyta), une nouvelle Dinophycée d'eau douce responsible de marées rouges. Algol. Stud. 95:15-29.

Ronquist F, Teslenko M, Van Der Mark P, Ayres DL, Darling A, Hohna S, Larget B, Liu L, Suchard MA, Huelsenbeck JP, 2012. MrBayes 3.2: efficient Bayesian phylogenetic inference and model choice across a large model space. Syst. Biol. 61:539-542.

Satta CT, Anglès S, Garcés E, Sechi N, Pulina S, Padedda BM, Stacca D, Lugliè A, 2014. Dinoflagellate cyst assemblages in surface sediments from three shallow Mediterranean lagoons (Sardinia, North Western Mediterranean Sea). Estuar. Coast. 37:646-63.

Satta CT, Pulina S, Reñé A, PadeddaBM, Caddeo T, Fois N, Lugliè A, 2020. Ecological, morphological and molecular characterization of Kryptoperidinium sp. (Dinophyceae) from two Mediterranean coastal shallow lagoons. Harmful Algae 97:101855.

Scholin CA, Herzog M, Sogin M, Anderson DM, 1994. Identification of group- and strain-specific genetic markers for globally distributed Alexandrium (Dinophyceae). 2. 
Sequence analysis of a fragment of the LSU rRNA gene. J. Phycol. 30:999-1011.

Smith VH, Tilnan GD, Nekola JC, 1999. Eutrophication: impacts of excess nutrient inputs of freshwater, marine and terrestrial ecosystems. Environ. Pollut. 100:179-196.

Stamatakis A, 2014. RAxML version 8: a tool for phylogenetic analysis and post-analysis of large phylogenies. Bioinformatics 30:1312-1313.

Strickland JDH, Parsons TR, 1972. A Practical Handbook of Seawater Analysis. Fisheries Research Board of Canada, Ottawa, Canada: 167 pp.

Takano Y, Hansen G, Fujita D, Horiguchi T, 2008. Serial replacement of diatom endosymbionts in two freshwater dinoflagellates, Peridiniopsis spp. (Peridiniales, Dinophyceae). Phycologia 47:41-53.

Tardio M, Tolotti M, Novarina G, Cantonati M, 2003. Ecological and taxonomic observations on the flagellate algae characterizing four years of enclosure experiments in Lake Tovel (Southern Alps). Hyrobiologia 502:285-296.

Utermohl H, 1958. Zurvervollkommung der quantitativenphytolankton-methodik. Mitt. d. Internat. Vereinig. f. Limnologie 9:1-39.

Watanabe MM, 2005. Freshwater culture media, p. 13-21. In: R.A. Andersen (ed.), Algal Culturing Tecniques. Elsevier Accademic Press.

Wu X, Li C, Chen L, Zhao Y, Li Y, Wang H, 2018. Responses of diel vertical migration behavior of Peridiniopsis to the distribution of carbon and phosphorus in Xiangxi River Bay, Three Geoges Reservoir. Hu Po Ke Kue 30:121-129. (In Chinese with English abstract).

Xu Y, Cai Q, Wang L, Kong L, Li D, 2010. Diel vertical migration of Peridiniopsis niei, Liu et al., a new species of dinoflagellates in an eutrophic bay of Three-Gorge Reservoir, China. Aquat. Ecol. 44:387-395.

You X, Luo Z, Su Y, Gu L, Gu H, 2015. Peridiniopsis jiulongensis, a new freshwater dinoflagellate with a diatom endosymbiont from China. Nova Hedwigia 101:313-326

Zhang H, Lin S, 2005. Phylogeny of dinoflagellates based on mitochondrial cytochrome $b$ and nuclear small subunit rDNA sequence comparisons. J. Phycol. 41:411-420.

Zhang Q, Guoxiang L, Hu Z, 2011. Morphological differences and molecular phylogeny of freshwater blooming species, Peridiniopsis spp. (Dinophyceae) from China. Eur. J. Protistol. 47:149-160.

Zhang X, Gu H, Luo Z, Sun J, 2013. Description of Peridiniopsis penardi (Lemmerman) Bourelly (Peridiniales, Dinophyceae) with its endosymbiotic diatom. Trans. Oceanol. Limnol. 1:97104. (In Chinese with English abstract).

Zhang Q, Liu G, Hu Z, 2014. Description of a new freshwater bloom-forming dinoflagellate with a diatom endosymbiont, Peridiniopsis minima sp. nov. (Peridiniales, Dinophyceae) from China. Algol. Stud. 145/146:119-133. 